\title{
On the potential of very high-resolution repeat DEMs in glacial and periglacial environments
}

\author{
J. Abermann ${ }^{1}$, A. Fischer ${ }^{2}$, A. Lambrecht ${ }^{2}$, and T. Geist ${ }^{3}$ \\ ${ }^{1}$ Austrian Academy of Sciences, Commission for Geophysical Research, Vienna, Austria \\ ${ }^{2}$ Institute of Meteorology and Geophysics, University of Innsbruck, Innsbruck, Austria \\ ${ }^{3} \mathrm{FFG}$ - Austrian Research Promotion Agency/ALR - Aeronautics and Space Agency, Vienna, Austria
}

Received: 9 June 2009 - Published in The Cryosphere Discuss.: 1 July 2009

Revised: 29 December 2009 - Accepted: 12 January 2010 - Published: 25 January 2010

\begin{abstract}
The potential of high-resolution repeat DEMs was investigated for glaciological applications including periglacial features (e.g. rock glaciers). It was shown that glacier boundaries can be delineated using airborne LIDARDEMs as a primary data source and that information on debris cover extent could be extracted using multi-temporal DEMs. Problems and limitations are discussed, and accuracies quantified. Absolute deviations of airborne laser scanning (ALS) derived glacier boundaries from ground-truthed ones were below $4 \mathrm{~m}$ for $80 \%$ of the ground-truthed values. Overall, we estimated an accuracy of $+/-1.5 \%$ of the glacier area for glaciers larger than $1 \mathrm{~km}^{2}$. The errors in the case of smaller glaciers did not exceed $+/-5 \%$ of the glacier area. The use of repeat DEMs in order to obtain information on the extent, characteristics and activity of rock glaciers was investigated and discussed based on examples.
\end{abstract}

\section{Introduction}

Glacial and periglacial environments have been changing rapidly in the past decades (e.g., Dyurgerov and Meier, 2000; Haeberli, 1999) as a result of climate change (e.g., Lemke et al., 2007; Trenberth et al., 2007). Determination of their actual geometry is crucial to the monitoring process and for understanding the short-term responses of their extent.

The mapping of glacier extent and volume changes using remote sensing techniques is a widely used and powerful tool. Various studies show both the potential and the limitations of using satellite data (e.g., Andreassen et al., 2008; DeBeer and Sharp, 2007; Paul et al., 2007; Kääb et al., 2002), airborne techniques such as photogrammetry (e.g., Würländer et al., 2004; Patzelt, 1980) or LIDAR (light detection and ranging, e.g., Geist and Stötter, 2007; Geist et al., 2003; Favey et al., 2002; Baltsavias et al., 2001a). Automatic or semi-automatic classification algorithms (Hendriks and Pellikka, 2007; Höfle et al., 2007; Kodde et al., 2007; Paul et al., 2002; Rott and Markl, 1999) are used to classify glacier areas.

However, the mapping of debris-covered glacier areas proves to be problematic in the case of both automatic and manual methods (e.g., Knoll and Kerschner, 2009; Paul et al., 2002; Hendriks and Pellikka, 2007). Fig. 1 illustrates the problem of glacier boundary delineation of complex glacier boundaries, addressed further on. Neither the highly resolved orthophotograph (Fig. 1b: $0.5 \mathrm{~m}$ spatial resolution) nor the RGB-composite of a Landsat scene of the Hintereisferner glacier margin (Fig. 1b: bands 4, 5 and 6 as proposed by Rott and Markl, 1999) allow for definite detection of the glacier boundary, including the debris-covered part of the glacier tongue as demonstrated later. Furthermore, the automatic mapping of small glaciers is difficult in particular from space (e.g., Paul et al., 2002). Lambrecht and Kuhn (2007) showed that $79 \%$ of all Austrian glaciers are smaller than $0.5 \mathrm{~km}^{2}$, and $43 \%$ are smaller than $0.1 \mathrm{~km}^{2}$.

The main aim of this study is thus to investigate the potential of a set of high-resolution DEMs to map glacier extents with sufficient accuracy, independent of their size and debris cover. Accuracies are quantified and limitations discussed. Further, we highlight the potential of repeat DEMs for interpretation of small-scale rock glacier surface elevation changes. 

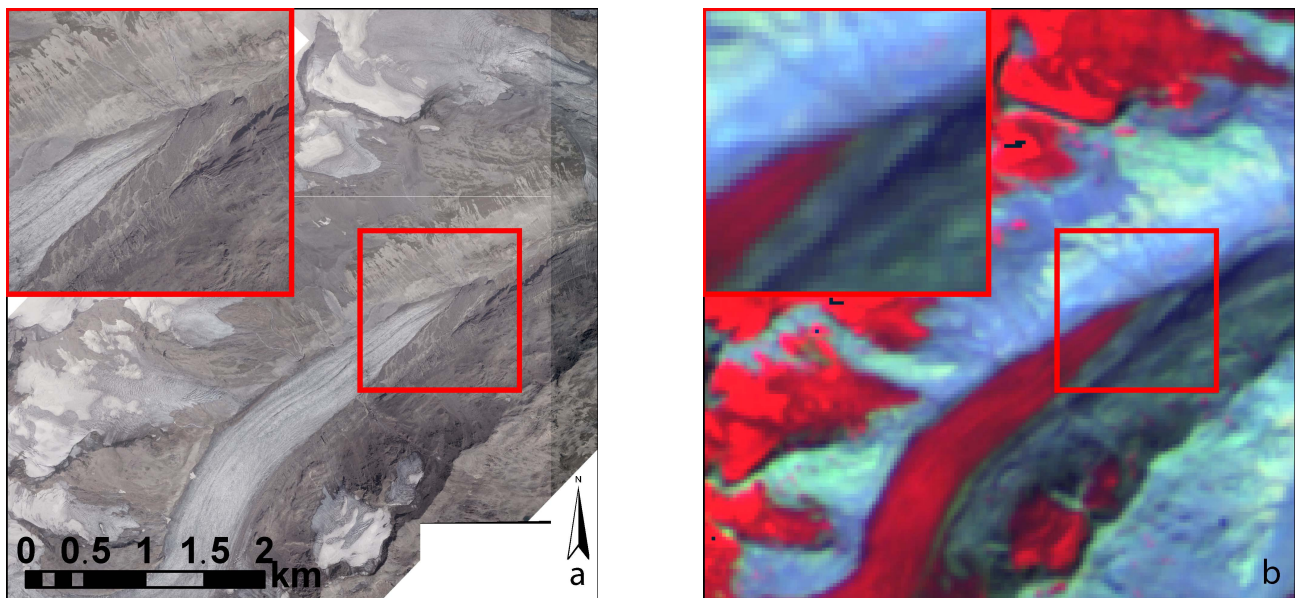

Fig. 1. (a) The orthophotograph (0.5 m spatial resolution) taken 2003, and (b) the Landsat 7 ETM+ scene (taken 10 September 2004) of the area around Hintereisferner, with the channels 4, 5, $6 \mathrm{H}$ as an RGB-composite. The red rectangle indicates the extent of the close-up in the upper left corner.

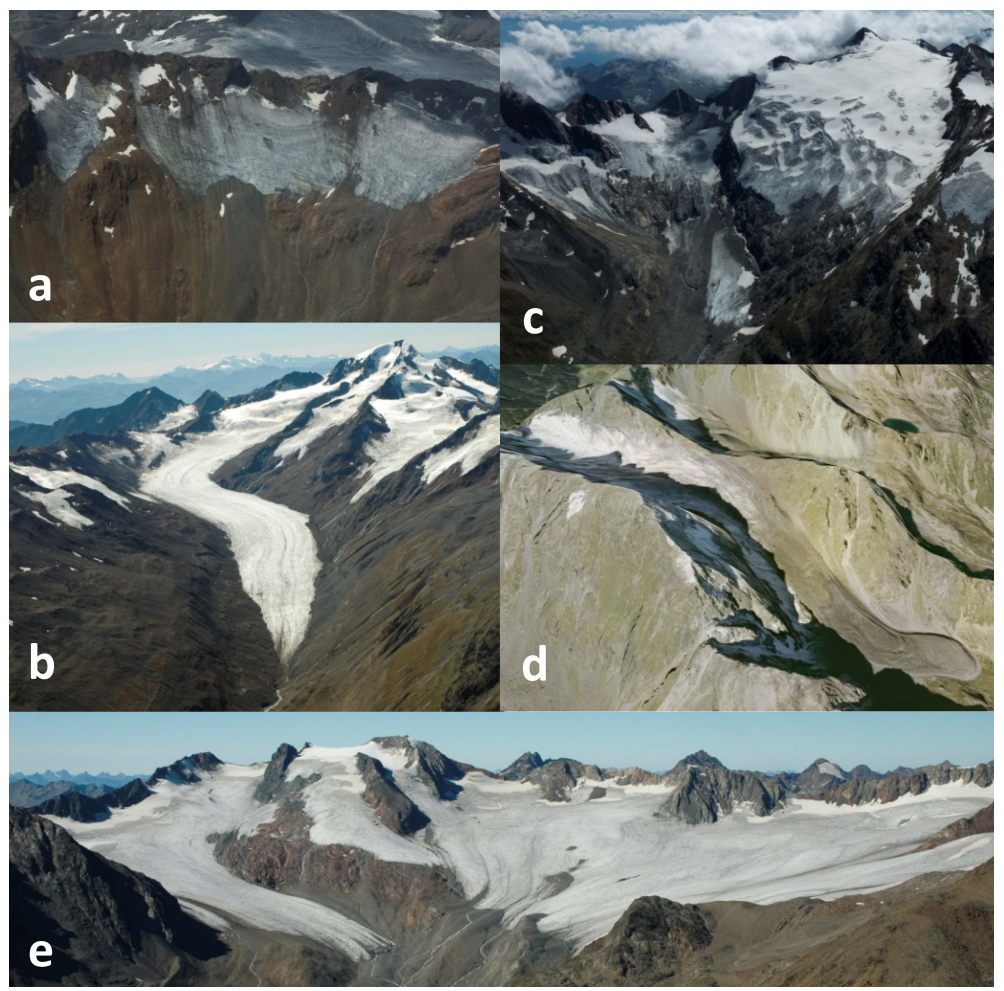

Fig. 2. Aerial photographs of (a) Mittlerer Guslarferner (9 September 2008), (b) Hintereisferner (9 September 2008), (c) Rotmoos- and Wasserfallferner (28 August 2009) and (e) Vernagtferner (28 August 2009). (d) is an oblique perspective of a SPOT-image of Reichenkar rock glacier presented in Google Earth (Google Earth, 2009).

\section{Test sites and data}

Four glaciers and one rock glacier in the Ötztal Alps and the neighboring part of the Stubai Alps (ca. $47^{\circ} \mathrm{N}, 11^{\circ} \mathrm{E}$ ) were chosen as test sites. Aerial photographs in Fig. 2 provide a view of the individual study sites. Local climatic con- ditions during the past four decades are described in Abermann et al. (2009). To test the glacier boundary delineation for a small, debris-free glacier, we chose Mittlerer Guslarferner (Fig. 2a). Nearby Hintereisferner (Fig. 2b) has been the object of extensive glaciological investigations over the past decades. This has resulted in a large number of DEMs, 


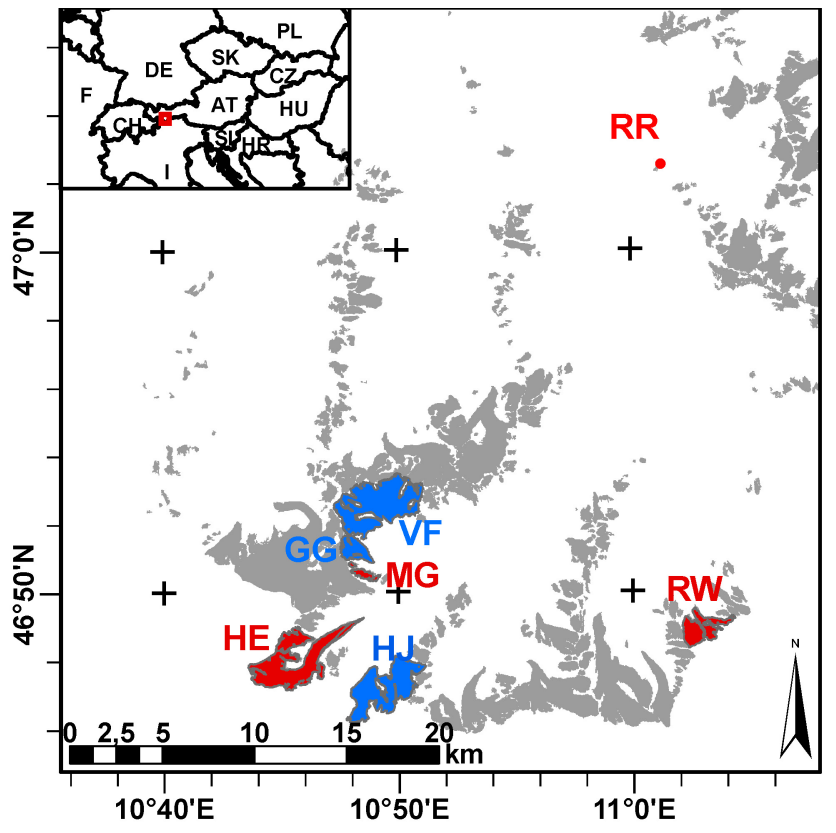

Fig. 3. The study area: Glaciers in the Ötztal and Stubai Alps (grey) with three reference glaciers (HE: Hintereisferner, MG: Mittlerer Guslarferner, RW: Rotmoos- und Wasserfallferner) and one rock glacier (red, RR: Reichenkar rock glacier). Ground truth has been performed for the blue glaciers (GG: Großer Guslarferner, HJ: Hochjochferner and VF: Vernagtferner) as well as Hintereisferner.

remote sensing data and ground truth. For this reason, Hintereisferner was chosen for the investigation of the performance of the data set on a debris-covered margin. Problems with glacier boundary delineations in firn areas are highlighted, using Rotmoosferner as an example (Fig. 2c); and ground truthing is demonstrated at Vernagtferner (Fig. 2e) and was performed on three more glaciers. The thoroughly investigated ice-cored Reichenkar rock glacier (Krainer et al., 2002; Krainer and Mostler, 2000, Fig. 2d) is used as an example to show potential applications for delineating rock glacier extents. Figure 3 shows a map of the whole study area with glaciers in the Ötztal and Stubai Alps (grey) and the example glaciers (red).

For the purpose of ground control, geodetically measured points are included. These were acquired with a theodolite and an electro-optical rangefinder (Kern, DM501) achieving an xyz-accuracy of less than $5 \mathrm{~cm}$ standard error (H. Schneider, personal communication, 2009). The results of the length change measurements are published annually by the Austrian Alpine Club (issues up to and including 2003/2004 named "Mitteilungen des Österreichischen Alpenvereins", after 2004/2005 named "Bergauf"; Patzelt, 2005; Patzelt, 2006). Within the study area these comparably accurate length change measurements were performed at the margins of Hintereisferner, Vernagtferner, Großer Guslarferner and Hochjochferner, totalling 118 measured points compared
Table 1. Summary of technical specifications of the LIDAR acquisition campaign of the regional government of Tyrol, 2006.

\begin{tabular}{ll}
\hline Sensor & Optech ALTM3100 \\
\hline Laser Wavelength & $1064 \mathrm{~nm}$ \\
Scan Frequency & $33 \mathrm{~Hz}$ \\
Scan angle & $+/-20^{\circ}$ \\
Point density & Minimum: 1 point $/ 4 \mathrm{~m}^{2}$ \\
Measurement frequency & $71 \mathrm{kHz}$ \\
Average flight height & $1100 \mathrm{~m} \mathrm{a.g.1.}$ \\
Mode & Last Pulse \\
Interpolation software & SCOP++ \\
Interpolation method & Moving Planes \\
Horizontal accuracy & $+/-0.3 \mathrm{~m}$ \\
Vertical accuracy & $+/-0.1 \mathrm{~m}$ \\
Spatial resolution & $1 \mathrm{~m}$ \\
\hline
\end{tabular}

using an independent method. These glaciers are colored blue in Fig. 3. We show the example of Vernagtferner in Sect. 4.5. Coincidentally these ground-based measurements, which were taken on 22 and 23 August 2006, deviate from the LIDAR acquisition date (23 August 2006) by one day at most.

DEMs with $10 \mathrm{~m}$ spatial resolution acquired in 1997, and high-resolution LIDAR-DEMs from 2006, were available for all test sites. The DEMs from 1997 were acquired during the compilation of the second Austrian glacier inventory using digital photogrammetry (Kuhn et al., 2009; Lambrecht and Kuhn, 2007; Würländer and Eder, 1998). The 2006 LIDARDEMs were acquired by the regional government of Tyrol. The technical specifications of this LIDAR acquisition campaign are summarized in Table 1.

Another set of LIDAR-DEMs covers a study area around Hintereisferner for which 14 DEMs were produced between 2001 and 2007. Relative horizontal accuracies are better than $1 \mathrm{~m}$ and relative vertical accuracies better than $0.3 \mathrm{~m}$ according to Geist and Stötter (2007), where more technical specifications of this acquisition campaign are described. For the application of our method three survey flights were chosen since they were acquired at a similar time of year (October 2001, 2004 and 2005) close to the minimum snow extent.

The example of Hintereisferner has been used to demonstrate the applicability and potential of the repeat highresolution DEMs as shown in Fig. 1. The orthophotograph (Fig. 1a) was acquired in the OMEGA project (e.g. Pellikka and Rees, 2009; Kuhn, 2007). The Landsat scene was acquired on 10 September 2004 (path 193, row 27, id LE71930272004254ASN01). Table 2 shows details on the acquisition dates of all data used, its accuracies as well as image and spatial resolution. 
Table 2. Summary of the acquisition dates as well as resolutions and accuracies of the data used in this study.

\begin{tabular}{|c|c|c|c|c|c|c|}
\hline Source data & Date & Band & $\begin{array}{l}\text { Image } \\
\text { resolution }[\mathrm{m}]\end{array}$ & $\begin{array}{c}\text { DEM } \\
\text { resolution }[\mathrm{m}]\end{array}$ & $\begin{array}{c}\text { Horizontal } \\
\text { accuracy [m] }\end{array}$ & $\begin{array}{c}\text { Vertical } \\
\text { accuracy }[\mathrm{m}]\end{array}$ \\
\hline Aerial photography & 11 September 1997 & & 1 & 10 & 1 & 0.7 \\
\hline LIDAR & 11 October 2001 & & - & 1 & $<1$ & $<0.3$ \\
\hline LIDAR & 5 October 2004 & & - & 1 & $<1$ & $<0.3$ \\
\hline LIDAR & 12 October 2005 & & - & 1 & $<1$ & $<0.3$ \\
\hline LIDAR & 23 August 2006 & & - & 1 & 0.3 & 0.1 \\
\hline Landsat & 10 September 2004 & $4,5,6 \mathrm{H}$ & 30 & - & ca. 30 & - \\
\hline Aerial photography & 12 August 2003 & & 0.5 & - & 1 & - \\
\hline
\end{tabular}

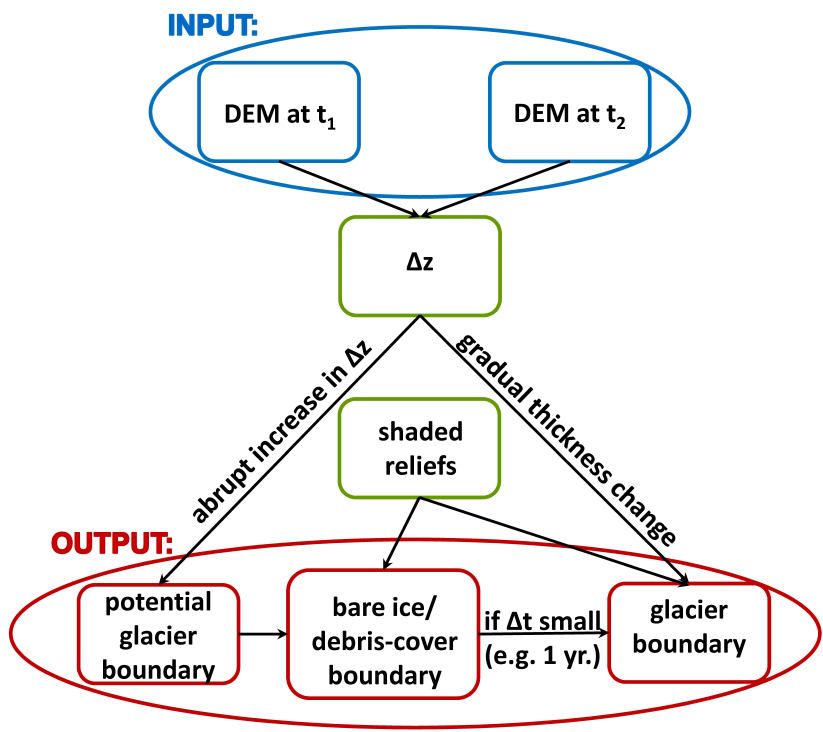

Fig. 4. Workflow of the glacier mapping procedure with multitemporal (high-resolution) DEMs.

\section{Methodology}

Glacier boundary delineation was performed following the schematic workflow as sketched in Fig. 4 , where $t_{1}$ is the point in time of the first and $t_{2}$ of the second DEM. To distinguish between glaciers and their surroundings, surface elevation changes between the two points in time were calculated. Investigating the course of surface elevation changes provided information on the actual glacier boundary as well as on debris-cover or dead-ice extent: a gradual increase of surface elevation loss from the glacier margin at $t_{1}$ upwards indicated a debris-free glacier tongue with a maximal change at the position of the glacier margin of $t_{2}$.

A glacier with debris cover evolves differently from bare ice due to the fact that thick debris cover reduces ablation (Kirkbride and Warren, 1999). For this reason, elevation differences between $t_{1}$ and $t_{2}$ are significantly smaller at the debris-covered parts and show instant increase at the place where debris cover meets bare ice. We used these differences to gain information about the occurrence and, depending on the time interval between the acquired DEMs, the extent of debris cover. Examples of these cases will follow in Sect. 4.

Two relief-shaded representations of the high-resolution DEM (in the following: shaded reliefs) at $t_{2}$ with different azimuth angles for illumination $\left(315^{\circ}\right.$ and $\left.135^{\circ}\right)$ were calculated to present optimal visualization of contrasts in different aspects. Taking advantage of the already existing glacier inventory from a previous date (Lambrecht and Kuhn, 2007), we then undertook a qualitative analysis of the ways in which ice thickness has evolved from the former glacier terminus position upwards. Indicating the existence of former glacier boundaries is not mandatory but it saves time, as these show where to expect glacier-covered areas. Nevertheless, even if a former data set of glacier boundaries is found to exist, it is advisable to test this using a difference raster, in order to prevent a glacier not captured in a previous study from escaping capture in a new one.

If a gradual increase in ice thickness loss from the former glacier margin upwards was detected, we set the glacier boundary directly by manually digitizing the strongest roughness change in the shaded reliefs via visual inspection. Upon detection of an abrupt increase in ice thickness loss, shaded reliefs were used to establish the boundary between bare ice and dead ice or debris-covered ice. The difference raster helped to determine the extent of the debris-covered areas in cases where the temporal resolution was high enough (e.g. 1 year). In cases where temporal resolution was lower (e.g., years to decades), the potential glacier boundary could be derived in areas where a significant thickness change had occurred.

Surface elevation changes are much smaller in accumulation zones of glaciers (Abermann et al., 2009). We therefore could only partly take advantage of the difference raster for boundary delineation and thus used the roughness changes in the shaded reliefs. If they were not distinct enough, we used orthophotographs to map the glacier extent in these areas. 

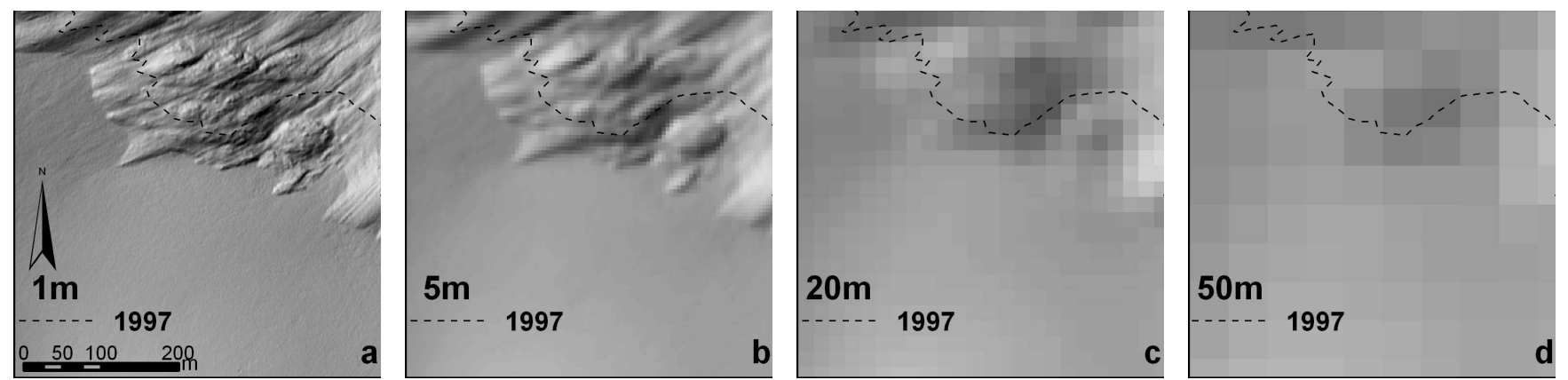

Fig. 5. Shaded reliefs of Mittlerer Guslarferner's margin calculated out of the LIDAR-DEMs with (a) the original $1 \mathrm{~m}$ and the resampled (b) $5 \mathrm{~m}$, (c) $20 \mathrm{~m}$ and (d) $50 \mathrm{~m}$ resolutions. The glacier margin of 1997 is dashed in all figures; the glacier margin of 2006 is not displayed in order to show the distinct roughness differences between rock and ice objectively.
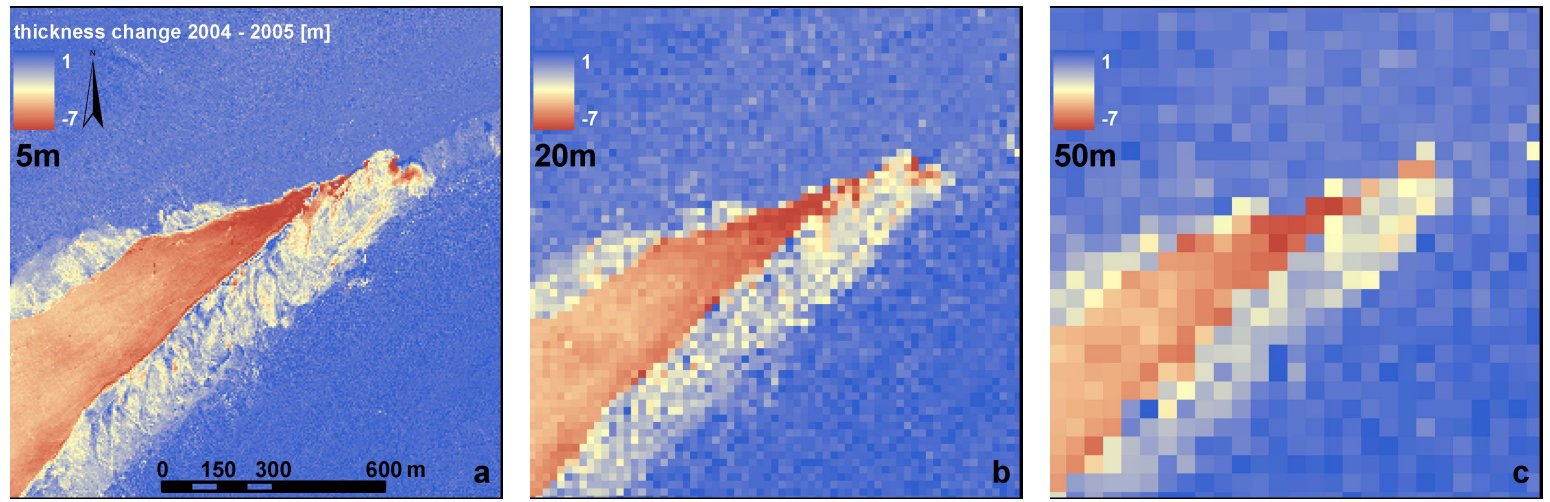

Fig. 6. Ice thickness changes between 2004 and 2005 using (a) $5 \mathrm{~m}$ spatial resolution, (b) $20 \mathrm{~m}$ resolution and (c) $50 \mathrm{~m}$ resolution for the tongue of Hintereisferner.

The influence of the spatial resolution of the DEM on the quality of the glacier boundary delineation with highresolution DEMs as a main data source is highlighted in Figs. 5 and 6. We calculated four shaded reliefs out of differently resampled DEMs (Fig. 5a-d) for a part of the margin of Mittlerer Guslarferner. A qualitative analysis of surface roughness differences is applicable for DEMs that exist at a resolution better than $5 \mathrm{~m}$. One-meter DEMs are optimal and allow the use of orthophotographs or any other additional information for glaciers without debris cover to be omitted (Fig. 5a). A spatial resolution of $20 \mathrm{~m}$ or higher fails to resolve roughness changes adequately (Fig. $5 \mathrm{c}$ and d).

Figure 6 shows as an analogy the ice thickness changes calculated from differently resampled DEMs at the margin of Hintereisferner (same extent as in Fig. 1). The differences between the rocky surroundings, the debris-covered part of the margin and the debris-free ice is visible up to the $50 \mathrm{~m}$ resolution. However, since the differences between the surface characteristics are small (compare noise in rocky surroundings with debris-covered part in Fig. $6 \mathrm{~b}$ and c), no significant conclusions can be drawn for spatial resolutions larger than $5 \mathrm{~m}$. Thus the proposed method is limited to highresolution remote sensing data.
While investigating the potential of a sequence of highresolution DEMs for rock glacier monitoring we were limited to an example where a photogrammetric DEM of 1997 and the LIDAR-DEM of 2006 exist (Reichenkar rock glacier) due to the lack of repeat LIDAR-DEMs. Surface elevation changes were calculated and their distribution analyzed in order to detect the margin of the rock glacier as well as the results from small- and larger-scale dynamics.

\section{Results}

We now highlight the results of the glacier boundary delineation, providing reference glaciers of different characteristics as examples (see 4.1.-4.4). The course of elevation changes from the former glacier boundary upwards is presented visually by profiles that are indicated on the maps and displayed as inserted figures. 

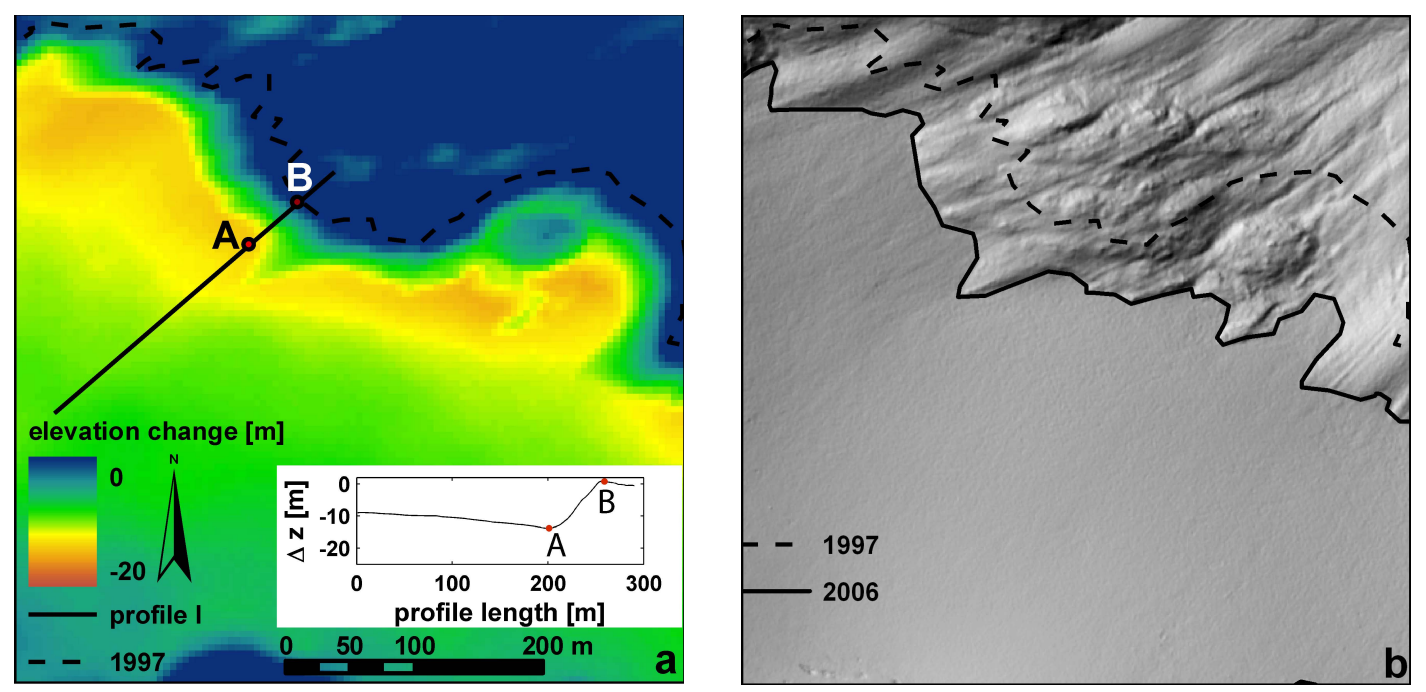

Fig. 7. (a) Elevation change 1997-2006 with the glacier boundary of 1997 (dashed) on Mittlerer Guslarferner and a profile of surface elevation changes inserted in the lower right corner. In (b) the shaded relief of the LIDAR-DEM 2006 is shown with the glacier boundary of 2006 (solid line). The same scene as in Fig. 5 is shown.

\subsection{Debris-free glacier tongue: the example of Mittlerer Guslarferner}

The small $\left(0.5 \mathrm{~km}^{2}\right)$ debris-free Mittlerer Guslarferner had a gradual loss in ice thickness from the former glacier margin (B) upwards (Fig. 7a, same extent as Fig. 5). Between B (glacier margin in 1997) and A (glacier margin in 2006), absolute values of surface elevation changes increased gradually up to about $13 \mathrm{~m}$ at $\mathrm{A}$ and decreased from A upwards, as shown in the inserted profile. An optimal delineation of the glacier extent was performed by following the pronounced roughness changes in the shaded reliefs as shown in Fig. $7 b$. Compare also Fig. 5, where the delineated glacier boundary was not added and thus the roughness changes are more clearly visible.

\subsection{Accumulation zone: the example of Rotmoosferner}

We achieved good results in large parts of the accumulation area by qualitatively analyzing the roughness changes in the shaded reliefs. In this way the glacier surface could be distinguished from its rocky surroundings. As suggested in UNESCO (1970) as well as Paul et al. (2009), we included adjacent perennial snow-covered areas in the glacier surface area. The acquisition dates of the LIDAR-DEMs (October and late August, see Table 2) were optimal: they were close to the minimum snow extent in the Alps when the surroundings of the glaciers were likely to be snow-free. In some cases also in the lower parts of the accumulation zone, our analysis of surface elevation changes helped us to decide which areas to include in the glacier extent. We also performed a qualitative analysis of aerial photographs which helped us reach conclusions about the remaining somewhat ambiguous areas. Fig. 8a provides an example of the firn area on Rotmoos- ferner. It was not possible, by analyzing the shaded relief of the DEM (black ellipse) alone, to tell whether it was partly debris-covered ice or consisted only of rocks. Our analysis of the surface elevation changes failed to yield a distinct answer since surface elevation changes were very minimal in this region. Fortunately, a qualitative comparison with an aerial photograph taken by the regional government of Tyrol in 2003 (TirisMaps, 2009) provided a strong indication. Crevasse patterns could be seen in this debris- or rockcovered part of the glacier (Fig. 8b).

\subsection{Debris-covered glacier margins: the example of Hintereisferner}

In cases where we identified an abrupt increase in elevation loss around the former glacier boundary, we followed a different workflow from the one in Fig. 4. An example of this is given in Fig. 9 for the margin of Hintereisferner (same extent as in Fig. 6). Figure 9a shows the differences calculated between 2001 and 2005. As UNESCO (1970) as well as Paul et al. (2009) suggested, adjacent debris-covered areas and dead-ice bodies have to be included in glacier inventories. In accordance with this, the areas in which a significant elevation change had occurred were included in the so-called "potential" glacier area (Fig. 9b). The significance of the potential glacier area depends on the temporal resolution of the multi-temporal DEMs. If the two DEMs used were acquired at widely differing points in time (e.g. decades), and if during this period a significant ice volume loss occurred, it may well be that ice that was stored beneath the debris cover was partly melted by the time of the second acquisition date. In such cases the additional use of multi-temporal DEMs should provide a clue as to where ice could still exist 


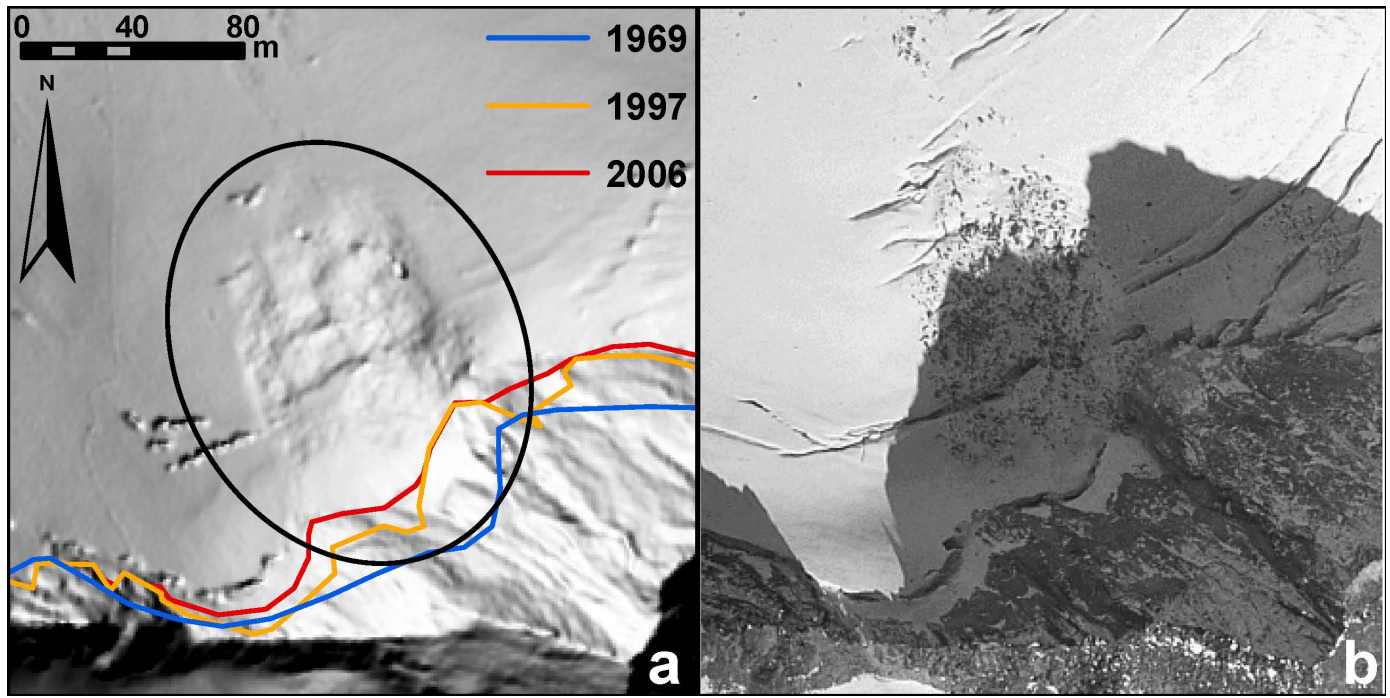

Fig. 8. (a) Rotmoosferner's firn area displayed as a shaded relief of the 2006 DEM with glacier margins of 1969 (blue), 1997 (orange) and 2006 (red) and the ambiguous area (black ellipse) as addressed in the text. (b) shows an aerial photograph of 2003.
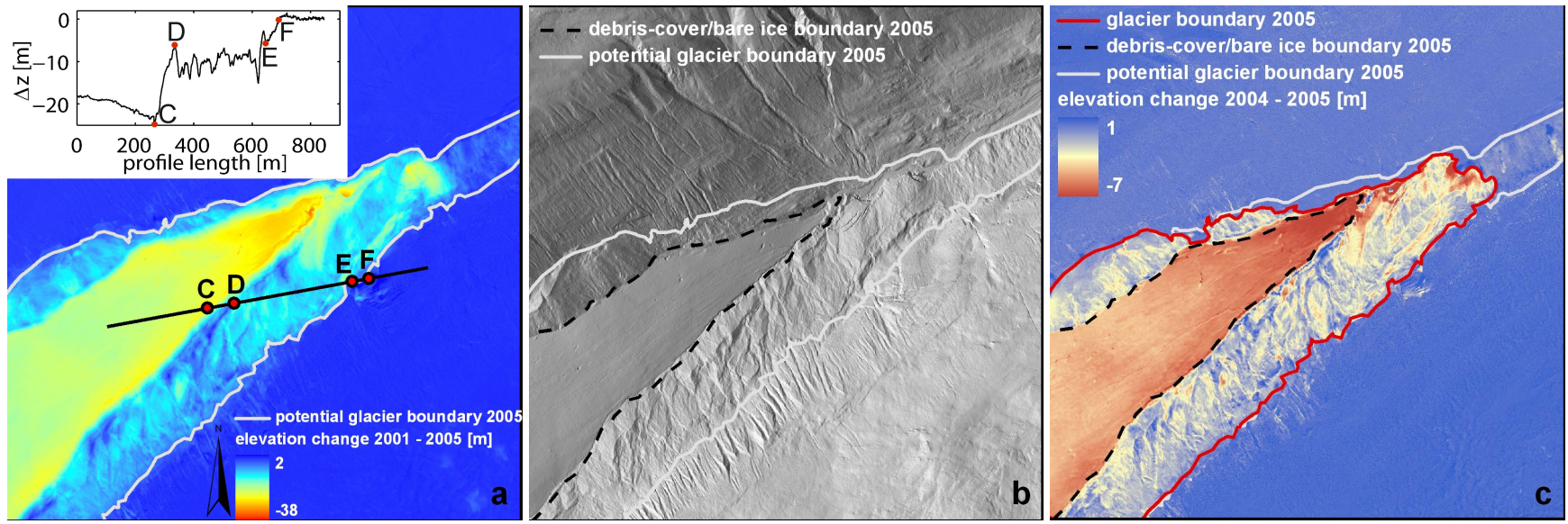

Fig. 9. In (a) the ice thickness changes between 2001 and 2005 are shown together with the potential glacier boundary (grey). A profile of surface elevation changes is inserted in the upper left corner. The calculated shaded relief from the 2005 DEM is shown in (b), including the debris-cover/bare ice boundary. Indicator 1 marks gully-formation that is discussed in Sect. 5. In (c), DEM-differences between 2004 and 2005 allow for the detection of the glacier boundary 2005.

below the debris cover. If the interval between the two DEMs is short (e.g. years, not decades), we conclude that in places where an elevation change has occurred, it may be assumed that there is still ice below. In our study area around Hintereisferner we had the advantage of a very good temporal resolution; therefore, the glacier extent could be determined very precisely using two DEMs with a one-year time difference (Fig. 9c).

The surface elevation changes along the profile in Fig. 9a allowed for a more detailed analysis comparing bare ice and debris-covered areas. From the profile starting point until $\mathrm{C}$, absolute values of surface elevation changes increased gradually (as compared to the example in Fig. 7) to more than $20 \mathrm{~m}$, since this is the bare-ice region. C coincides with the debris-cover/bare-ice boundary (Fig. 9b). Within a short distance only, between $\mathrm{C}$ and $\mathrm{D}$, surface elevation changes decreased rapidly to around $10 \mathrm{~m}$. This transition between debris-free and debris-covered ice can follow a lesspronounced shape, depending on the thickness of the debris layer and the topography of the surroundings. A decrease in thickness changes compared to the bare ice is to be expected. The insulation of the debris between $\mathrm{D}$ and $\mathrm{E}$ thus reduced ablation by about half for the example given. Thickness variations in the debris layer resulted in significant ablation variations on a smaller scale (e.g., meters to tens of meters). Between $\mathrm{E}$ and $\mathrm{F}$ the debris cover thickened and the transition from debris-covered ice to ice-free surroundings took place. $\mathrm{F}$ coincided with the potential glacier extent. 


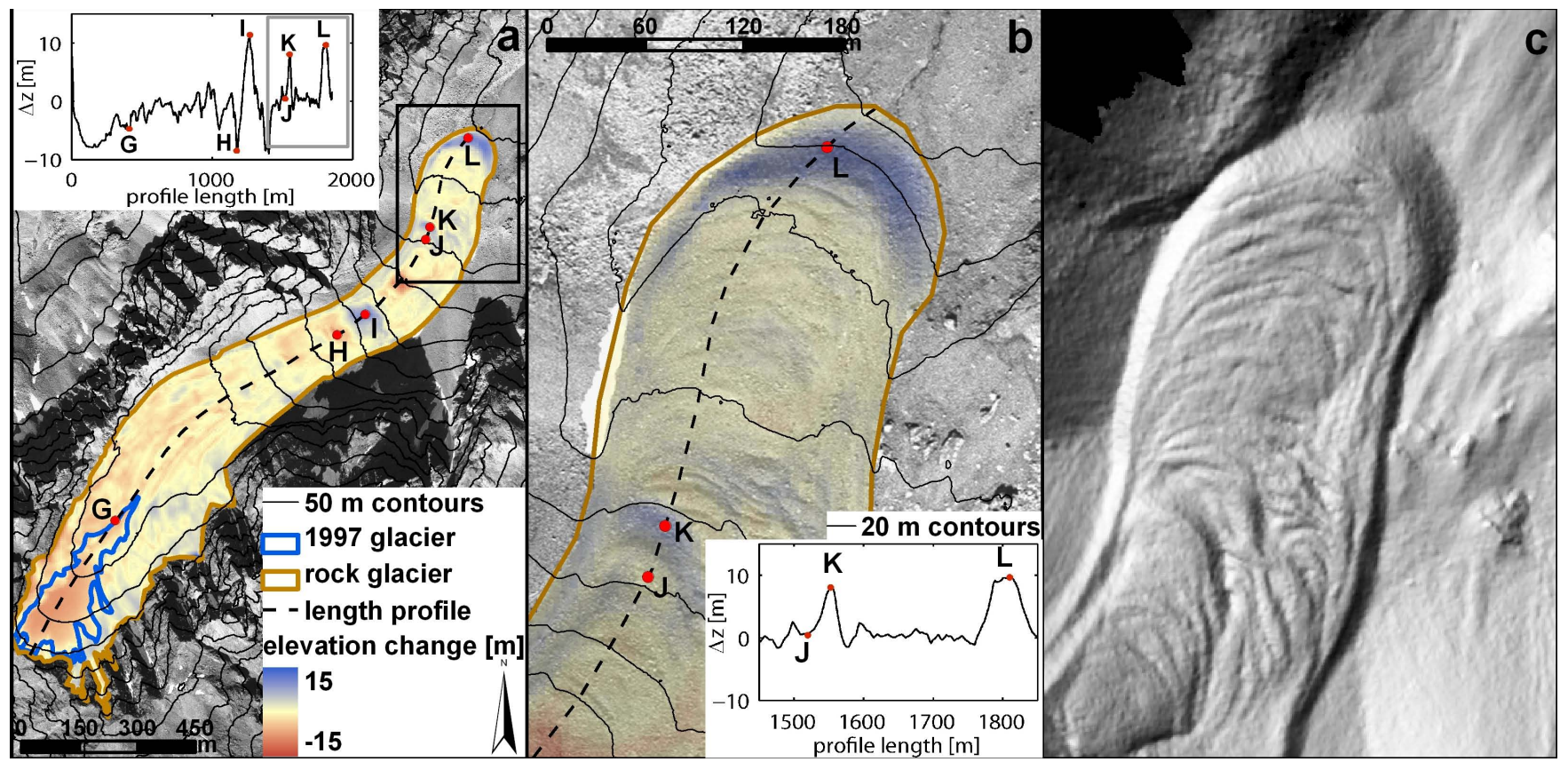

Fig. 10. Reichenkar rock glacier at $47^{\circ} 03^{\prime} 56^{\prime \prime} \mathrm{N}, 11^{\circ} 02^{\prime} 56^{\prime \prime} \mathrm{E}$ : (a) shows an overview of the area around Reichenkar rock glacier with the glacier boundary 1997 in blue and the rock glacier's extent of 2006 in orange. Surface elevation changes are shown in a color scheme and the elevation changes along the length profile (dashed in the map) are plotted in the inserted rectangle (upper left corner). The black rectangle on the upper right marks the extent of (b) and (c). (b) shows surface elevation changes with the same color scheme as in (a) with $50 \%$ transparency and the orthophotograph of 1997 below. (c) displays a shaded relief calculated from the LIDAR-DEM 2006.

\subsection{Potential for rock glacier monitoring: Reichenkar rock glacier}

Another interesting mode of application of LIDAR and multi-temporal DEMs is the mapping and monitoring of rock glaciers (as mentioned in the literature, e.g. Kääb, 2008a). Figure 10a shows Reichenkar rock glacier with the orthophotograph of 1997 in the background and surface elevation changes (1997-2006) in a color code. Over large parts of the rock glacier a surface elevation loss occurred between 1997 and 2006 due to the comparably thick ice core of the rock glacier (between 30 and $40 \mathrm{~m}$ (Krainer et al., 2002) that was gradually melting out. The most negative values were in the uppermost part (upwards from G) where a rock-free glacier (Reichenkarferner, blue line, Lambrecht and Kuhn, 2007) transforms into the rock glacier. The longitudinal profile inserted in Fig. 10a reveals an interesting feature at markers $\mathrm{H}$ and $\mathrm{I}$, where an elevation loss at $\mathrm{H}$ is followed by an elevation gain further downstream (I). This could be attributed to the propagation of a ridge downwards, a small-scale phenomenon connected with rock glacier elevation changes that is also found in other studies (e.g. Kääb and Vollmer, 2000). Even smaller-scale change patterns were found further down the longitudinal profile, where a significant surface elevation gain is visible at $\mathrm{K}$ (up to $8 \mathrm{~m}$; the close-up of this region is found in Fig. 10b with a zoom into the profile inserted). Hardly any change in elevation was observed upwards from
$\mathrm{K}$ (e.g. at J) indicating a compressive flow of the rock glacier due to a change in surface slope from steeper (upwards from $\mathrm{K})$ to flatter (from $\mathrm{K}$ downwards) terrain. In this part of the rock glacier, considerable velocities of up to $4 \mathrm{ma}^{-1}$ were measured by Krainer and Mostler (2006). A pronounced positive surface elevation change occurred at the rock glacier's snout with up to $10 \mathrm{~m}$ surface elevation gain at $\mathrm{L}$ This accompanied an advance of the snout of about $25 \mathrm{~m}$ in 9 years. This result fits well to measured horizontal flow velocities between 2.5 and $2.9 \mathrm{ma}^{-1}$ at the central part of the rock glacier's snout as measured by Krainer and Mostler (2006). The distinct snout of the rock glacier can be delineated very well manually following the pronounced roughness changes of the shaded relief (Fig. 10c).

\subsection{Accuracy and ground truth}

The accuracy estimation of the proposed method was achieved in different ways. Given that the method is based on a manual delineation, we had to anticipate and deal with interpretation errors. To this end, we first compared the results obtained by two different parties for certain glaciers. The deviation was less than $1 \%$ of the total area. In addition, we undertook random evaluations of some glaciers of different size categories. This produced one maximum and one minimum extent by including/excluding each of the ambiguous areas, respectively. The resulting glacier areas appear not to 


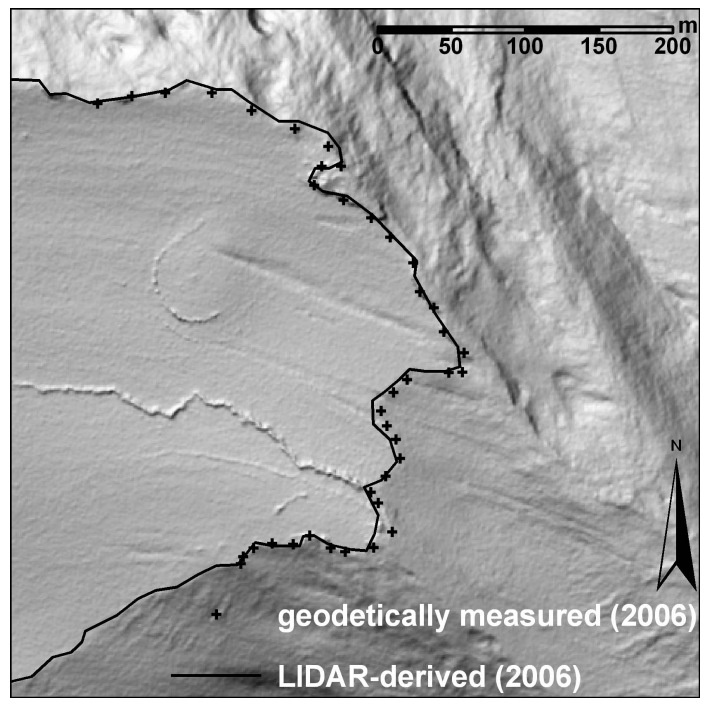

Fig. 11. The glacier margin of Vernagtferner with the LIDARderived boundary (solid) and the geodetically measured one (crosses).

have deviated from each other by more than $+/-1.5 \%$ of the total glacier-covered area for glaciers bigger than $1 \mathrm{~km}^{2}$, and up to $+/-5 \%$ for smaller glaciers.

Further to our application of this essentially qualitative approach that allowed for estimation of a relative error in the overall glacier area, we demonstrated a more quantitative one for all available geodetically measured (combined laser ranger and theodolite) points. They were acquired through the length-change measurement service of the Austrian Alpine Club. Figure 11 shows the delineated glacier boundary of Vernagtferner along with the geodetically measured points (crosses). Both the LIDAR-DEM and the field measurements coincidentally derive from the same date (22 August 2006).

By analogy, we implemented this data as ground truth for 3 more glaciers (Großer Guslarferner, Hochjochferner and Hintereisferner). This resulted in 118 measured points with which to compare the LIDAR interpretation. Figure 12 shows the resultant cumulative relative occurrence of the individual point distances sorted according to their absolute deviation. This can be interpreted as the relative occurrence of measured spots that lie closer to the reference measurement (geodetically) than the respective distance plotted at the yaxes (e.g., $85 \%$ of all reference points are within $4 \mathrm{~m}$ distance of the margin derived in this paper, or $95 \%$ within $8 \mathrm{~m}$ ). However, while these values are valid for glaciers of different size categories, their impact on the overall area accuracy depends on the size of the glacier itself.

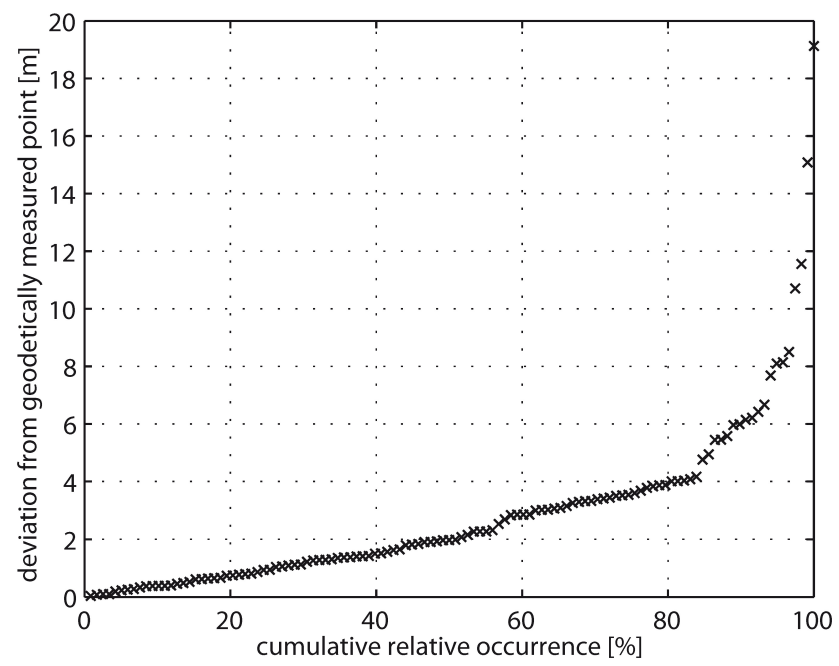

Fig. 12. Absolute deviations of the glacier boundary delineation performed in this study from the geodetically measured margin and their cumulative relative occurrences.

\section{Discussion}

Figure 13 provides an overview of the spatial resolution and the vertical accuracy of DEMs typically used in glaciology. It also shows the orders of magnitude of the typical mean annual thickness loss of all Austrian glaciers in the last decade (Abermann et al., 2009; Kuhn et al., 2009; and Lambrecht and Kuhn, 2007), of the typical ice thickness loss at debrisfree as well as debris-covered parts of Hintereisferner between 2001 and 2005, and of the ice thickness loss at the debris-free margin of Hintereisferner between 1953 and 2003 (Fischer et al., accepted) on the right side of the figure. The remote sensing data outside the rectangular box (orthophotographs and Landsat data) do not include topographic information. References for the individual data sets are given in brackets. The applicability of ice thickness changes for the detection of glacier boundaries depends on the magnitude of elevation change (time difference, climate signal) compared to the root sum square of the vertical accuracies of the DEMs applied. The use of LIDAR-DEMs together with DEM 1997 is thus a comparatively accurate option in terms of both the achieved horizontal resolution and the vertical accuracies.

Compared to other data sets used for glacier boundary delineation, the proposed sets have the advantage of enabling the debris-covered and dead-ice areas to be delineated as well. This had been pointed out, e.g., by Hendriks and Pellikka (2007), as a major disadvantage of multi-spectral methods. Knoll and Kerschner (2009), who worked with LIDAR but did not have multi-temporal DEMs, also addressed this problem.

In order to make use of this advantage, it is worth mentioning the order of magnitude that these surface elevation changes must have in order to be able to definitely distinguish 

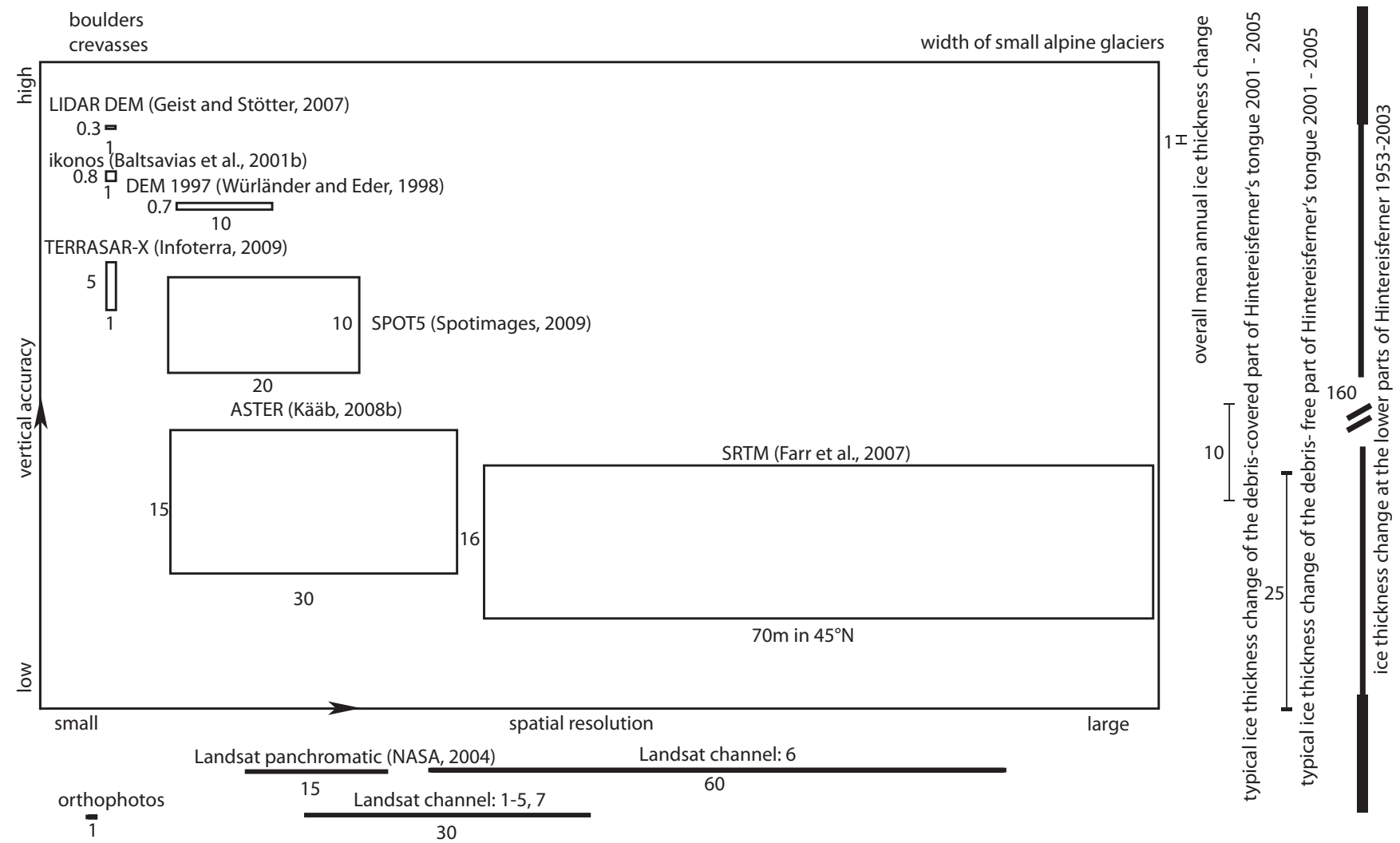

Fig. 13. Schematic distribution of spatial resolution vs. vertical accuracy of commonly used remote sensing data. Orthophotographs and Landsat-scenes do not include vertical information. Typical overall mean annual ice thickness change in Austria's glaciers, values of ice thickness change on debris-free and debris-covered parts of Hintereisferner's glacier margin (2001-2005) along with Hintereisferner's ice thickness loss (1953-2003) is displayed on the right. The lengths and widths of the boxes are scaled, with all numbers in meters. References appear in brackets.

Table 3. Accuracy of the DEM-differences for the examples provided in the paper.

\begin{tabular}{lcccccc}
\hline & DEM1 & $\varepsilon_{\text {DEM1 }[\mathrm{m}]}$ & DEM2 & $\varepsilon_{\text {DEM2 }[\mathrm{m}]}$ & $\Delta \mathrm{t}$ & $\varepsilon_{\Delta z}[\mathrm{~m}]$ \\
\hline Ex. Guslarferner (Fig. 6) & DEM 1997 & $+/-0.7$ & LIDAR 2006 & $+/-0.3$ & $9 \mathrm{yrs}$ & $+/-0.8$ \\
Ex. Hintereisferner (Fig. 10a) & LIDAR 2001 & $+/-0.1$ & LIDAR 2005 & $+/-0.1$ & $4 \mathrm{yrs}$ & $+/-0.1$ \\
Ex. Hintereisferner (Fig. 10c) & LIDAR 2004 & $+/-0.1$ & LIDAR 2005 & $+/-0.1$ & $1 \mathrm{yr}$ & $+/-0.2$ \\
Ex. Reichenkar rock glacier (Fig. 14) & DEM 1997 & $+/-0.7$ & LIDAR 2006 & $+/-0.3$ & $9 \mathrm{yrs}$ & $+/-0.8$ \\
\hline
\end{tabular}

them from noise introduced by errors in the DEMs. Applying the law of error propagation according to Etzelmüller (2000), the error from the DEM differences $\left(\varepsilon_{\Delta z}\right)$ is the root of the sum of square errors of the individual DEMs $\left(\varepsilon_{\mathrm{DEM} 1}\right.$ and $\varepsilon_{\text {DEM2), }}$

$\varepsilon_{\Delta z}=\sqrt{\varepsilon_{\mathrm{DEM} 1}^{2}+\varepsilon_{\mathrm{DEM} 2}^{2}}$.

For the data sets presented in this study, values of $\varepsilon_{\Delta z}$ are summarized in Table 3. For DEM combinations using other data sets $\varepsilon_{\Delta z}$ can be estimated with the vertical accuracies as shown in Fig. 13.
Processes resulting in surface elevation change on ice-free terrain (such as denudation, washout, rockfall or gully formation) could also be misinterpreted as glacier-induced elevation change should they reach the typical orders of magnitude of the latter. Hallet et al. (1996) report "effective rates of glacial erosion" in the Swiss Alps to be around $1 \mathrm{~mm} / \mathrm{a}$. Wittmann et al. (2007) quantify "denudation rates" at about $0.9 \pm 0.3 \mathrm{~mm} / \mathrm{a}$, the same as for the Swiss Alps. Since they are far smaller than typical elevation changes caused by icemelt, these processes can be neglected, even if only elevation changes within one year are considered (e.g., Fig. 9c, cf. typical rates of surface elevation change, Fig. 13). Gully 
formation along lateral moraines shortly after glacier recession can exceed these values, from typically $23 \mathrm{~mm} / \mathrm{a}$ (Ballantyne, 2002) to $151 \mathrm{~mm} / \mathrm{a}$ (Curry et al., 2005) on different Alpine sites. The maximum values found by Schiefer and Gilbert (2007) at $1.5 \mathrm{~m} / \mathrm{a}$ can be taken as an extreme case of non-glacier-related elevation change. While such formations are visible in a shaded relief of the DEM (Fig. 9b, indicator 1) they do not coincide with strong elevation change, which means that they were formed before 2001. Had they been formed between the DEMs studied, their longitudinal shape would have been visible in the DEM differences. This is one more reason why we applied the method manually, excluding such structures from the resulting glacier area. Rockslides can also cause considerable surface lowering, which might be misinterpreted as glacier area. But they invariably appear with a significant mass gain at the lower section of the rockslide and can thus be distinguished easily.

Another advantage of the glacier boundary delineation with very high resolution DEMs is the ability to implicitly derive volume changes also for very small glaciers, where many other remote sensing data sets fail, simply due to their large spatial resolution or considerable vertical errors (cf. Figs. 5, 6 and 13).

To minimize errors due to interpretation of surface elevation changes introduced by seasonal snow cover we mainly incorporated information from DEM differencing to the ablation areas. In these parts of the glacier fresh snow cover is not significant at the data acquisition dates (late summer or early autumn) compared to the strong elevation changes due to negative mass balances of the last years.

A major disadvantage of the method proposed is the considerable manual digitization effort that is necessary for the derivation of glacier boundaries, requiring between 0.5 and $2 \mathrm{~h}$ per glacier, depending on its complexity and size.

\section{Conclusions}

The inclusion of multi-temporal DEMs with a relative vertical accuracy significantly better than the ice thickness change over the investigated period improves the accuracy of glacier boundary mapping. This method is well suited to study areas with a comparably small extent, where an accurate knowledge of glacier area and volume change is needed, since it requires considerable manual digitization. One great advantage compared with other techniques for glacier boundary delineation is the high degree of accuracy achieved for the delineation of small glaciers (e.g., $<0.5 \mathrm{~km}^{2}$ ). Combining this with additional information such as multi-temporal DEMs and orthophotographs or other remote sensing data further improves the result. A broader application of the developed method was performed by Abermann et al. (2009): a regional update of an existing glacier inventory was undertaken. In addition, a new inventory is planned for other regions in Austria based on this methodology. Geophysical investigations of dead-ice regions could provide further insight into, and better ground truth, regarding these areas. It may well be an interesting topic for future study.

The better the vertical accuracy and the horizontal resolution of the DEMs, the shorter is the time period between the acquisition of the DEMs that is needed to obtain statistically significant elevation changes. When applied to the climatic conditions of glaciers closer to a steady state, this mapping procedure would be less successful as surface elevation changes would also be smaller. The accuracy of the glacier boundary delineation has proven higher in areas with large elevation change, i.e., low elevations and bare ice.

A sequence of multi-temporal airborne LIDAR-DEMs also covering rock glaciers will enhance the importance of this application for conducting studies on detailed elevation changes in creeping permafrost, including the implication of volume changes.

The use of multi-temporal DEMs will be of significant importance for future glaciological applications. The number of accurate high-resolution DEMs is increasing with both airborne and satellite data. The predicted future climate change (Trenberth et al., 2007) will result in continuing glacier volume and area loss. For this reason this method may be extended further and it is planned to make use of the information from high-resolution surface elevation changes to develop a semi-automatic glacier boundary delineation algorithm.

Acknowledgements. This study was funded by the Commission for Geophysical Research, Austrian Academy of Sciences. The LIDAR-DEM 2006 was acquired by the Regional Government of Tyrol. The authors would like to thank M. Kuhn and C. Knoll for their comments, S. Braun-Clarke, E. Dryland and L. Raso, for proofreading the paper as native English speakers, H. Schneider for providing the data for ground truthing and $\mathrm{M}$. Attwenger for providing information on the LIDAR-DEM. Two anonymous referees and the paper's editor, A. Kääb, are gratefully acknowledged for constructive remarks and useful suggestions which improved the manuscript considerably.

Edited by: A. Kääb

\section{References}

Abermann, J., Lambrecht, A., Fischer, A., and Kuhn, M.: Quantifying changes and trends in glacier area and volume in the Austrian Ötztal Alps (1969-1997-2006), The Cryosphere, 3, 205215, 2009,

http://www.the-cryosphere-discuss.net/3/205/2009/.

Andreassen, L. M., Paul, F., Kääb, A., and Hausberg, J. E.: Landsatderived glacier inventory for Jotunheimen, Norway, and deduced glacier changes since the 1930s, The Cryosphere, 2, 131-145, 2008,

http://www.the-cryosphere-discuss.net/2/131/2008/.

Ballantyne, C. K.: Paraglacial geomorphology, Quaternary Sci. Rev., 21, 1935-2017, 2002. 
Baltsavias, E. P., Favey, E., Bauder, A., Bösch, H., and Pateraki, M.: Digital surface modelling by airborne laser scanning and digital photogrammetry for glacier monitoring, The Photogrammetric Record, 17(98), 243-273, 2001a.

Baltsavias, E. P., Pateraki, M., and Zhang, L.: Radiometric and geometric evaluation of IKONOS GEO images and their use for 3D building and modelling, Proceedings of the ISPRS Workshop "High Resolution Mapping from Space 2001", Hannover, Germany, 19-21 September 2001, 2001b.

Curry, A. M., Cleasby, V., and Zukowskyj, P.: Paraglacial response of steep, sediment-mantled slopes to post-"Little Ice Age" glacier recession in the central Swiss Alps, J. Quaternary Sci., 21, 211-225, 2005.

DeBeer, C. M. and Sharp, M. J.: Recent changes in glacier area and volume within the southern Canadian Cordillera, Annals of Glaciology, 46, 215-221, 2007.

Dyurgerov, M. B. and Meier, M. F.: Twenthieth century climate change: Evidence from small glaciers, PNAS, 97(4), 1406-1411, 2000.

Etzelmüller, B.: On the quantification of surface changes using gridbased digital elevation models (DEMs), Transactions in GIS, 4(2), 129-143, 2000

Farr, T. G., Rosen, P., Caro, E., et al.: The Shuttle Radar Topography Mission, Rev. Geophys., 45, RG2004, doi:10.1029/2005RG000183, 2007.

Favey, E., Wehr, A., Geiger, A., and Kahle, H.-G.: Some examples of European activities in airborne laser techniques and an application in glaciology, J. Geodyn., 34, 347-355, 2002.

Fischer, A.: Glaciers and climate change: Interpretation of 50 years of direct mass balance of Hintereisferner, Global Planet. Change, doi:10.1016/j.gloplacha.2009.11.014, accepted, 2010.

Geist, T., Lutz E., and Stötter, J.: Airborne laser scanning technology and its potential for applications in glaciology, International Archives of Photogrammetry, Remote Sensing and Spatial Information Science, Vol. XXXIV, part 3/W13, 101-106, 2003.

Geist, T. and Stötter, J.: Documentation of glacier surface elevation change with multi-temporal airborne laser scanner data case study: Hintereisferner and Kesselwandferner, Tyrol, Austria, Zeitschrift für Gletscherkunde und Glazialgeologie, 41, 77106, 2007.

Google Earth, $47^{\circ} 2^{\prime} 55^{\prime \prime} \mathrm{N} 11^{\circ} 1^{\prime} 55^{\prime}$ E, last access: 18 September 2009.

Haeberli, W., Frauenfelder, R., Hoelzle, M., and Maisch, M.: On rates and acceleration trends of global glacier mass changes, Geogr. Ann. A, 81(4), 585-591, 1999.

Hallet, B., Hunter, L., and Bogen, J.: Rates of erosion and sediment evacuation by glaciers: A review of field data and their implications, Global Planet. Change, 12, 213-235, 1996.

Hendriks, J. P. M. and Pellikka, P.: Semi-automatic glacier delineation from Landsat imagery over Hintereisferner, Zeitschrift für Gletscherkunde und Glazialgeologie, 41, 55-75, 2007.

Höfle, B., Geist, T., Rutzinger, M., and Pfeifer, N.: Glacier surface segmentation using airborne laser scanning point cloud and intensity data, International Archives of Photogrammetry, Remote Sensing and Spatial Information Sciences, Vol. XXXVI/3, 195200, 2007.

InfoTerra: 3D topographic mapping with TerraSAR-X. Unique mapping concepts using high-resolution spaceborne SAR, 2009.

Kääb, A.: Remote sensing of permafrost - related problems and hazards, Permafrost Periglac., 19, 107-136, 2008a.

Kääb, A.: Glacier volume changes using ASTER satellite stereo and ICESat GLAS laser altimetry. A test study on Edgeoya, Eastern Svalbard, IEEE Transactions on Geoscience and Remote Sensing, 46(10), 2823-2830, 2008b.

Kääb, A., Paul, F., Maisch, M., and Häberli, W.: The new remotesensing-derived Swiss Glacier Inventory: II. First results, Annals of Glaciology, 34, 362-366, 2002.

Kääb, A. and Vollmer, M.: Surface geometry, thickness changes and flow fields on creeping mountain permafrost: Automatic extraction by digital image analysis, Permafrost Periglac., 11, 315-326, 2000.

Kirkbride, M. P. and Warren, C. R.: Tasman Glacier, New Zealand: 20th-century thinning and predicted calving retreat, Global Planet. Change, 22, 11-28, 1999.

Knoll, C. and Kerschner, H.: A glacier inventory for South Tyrol, Italy, based on airborne laser scanner data, Annals of Glaciology, 50(53), 46-52, 2009.

Kodde, M., Pfeiffer, N., Gorte, B., Geist, T., and Höfle, B.: Automatic glacier surface analysis from airborne laser scanning, ISPRS Workshop Laser Scanning 2007 XXXVI Part 3/W52, 221226, 2007.

Krainer, K. and Mostler, W.: Reichenkar Rock Glacier, a glacial derived debris-ice system in the Western Stubai Alps, Austria, Permafrost Periglac., 11, 267-275, 2000.

Krainer, K. , Mostler, W., and Span, N.: A glacier derived, ice-cored rock glacier in the western Stubai Alps (Austria): Evidence from exposures and ground penetrating radar investigation, Zeitschrift für Gletscherkunde und Glazialgeologie, 38(Eq. 1), 21-34, 2002.

Krainer, K. and Mostler, W.: Flow velocities of active rock glaciers in the Austrian Alps, Geogr. Ann. A., 88(4), 267-280, 2006.

Kuhn, M.: Zeitschrift für Gletscherkunde und Glazialgeologie, 41, Innsbruck, Austria, 232 pp., 2007.

Kuhn, M., Lambrecht, A., Abermann, J., Patzelt, G., and Gross, G.: Projektbericht 10. Die österreichischen Gletscher 1998 und 1969, Flächen- und Volumenänderungen, Verlag der österreichischen Akademie der Wissenschaften, Wien, Austria, 128 pp., 2009.

Lambrecht, A. and Kuhn, M.: Glacier changes in the Austrian Alps during the last three decades, derived from the new Austrian glacier inventory, Annals of Glaciology, 46, 177-184, 2007.

Lemke, P., Ren, J., Alley, R. J., et al.: Observations: Changes in Snow, Ice and Frozen Ground, in: Climate Change 2007, The Physical Science Basis, Contribution of Working Group I to the Fourth Assessment Report of the Intergovernmental Panel on Climate Change, edited by: Solomon, S., Qin, D., Manning, M. et al., Cambridge University Press, Cambridge, United Kingdom and New York, NY, USA, 2007.

Patzelt, G.: The Austrian glacier inventory: status and first results. Riederalp Workshop 1978 - World Glacier Inventory, IAHS, 1980.

Patzelt, G.: Gletscherbericht 2003/2004, Sammelbericht über die Gletschermessungen des Oesterreichischen Alpenvereins im Jahre 2004, Mitteilungen des Oesterreichischen Alpenvereins, 60(130), 24-31, 2005.

Patzelt, G.: Gletscherbericht 2004/2005, Sammelbericht über die Gletschermessungen des Österreichischen Alpenvereins im Jahre 2005, Bergauf, 2, 6-11, 2006.

Paul, F., Kääb, A., Maisch, M., Kellenberger, T. W., and Häberli, 
W.: The new remote-sensing-derived Swiss Glacier Inventory: I. methods, Annals of Glaciology, 34, 355-361, 2002.

Paul, F., Kääb, A. and Haeberli, W.: Recent glacier changes in the Alps observed from satellite: Consequences for future monitoring strategies, Global Planet. Change, 56(1/2), 111-122, 2007.

Paul, F., Barry, R., Cogley, G., Frey, H., Haeberli, W., Ohmura, A., Ommanney, S., Raup, B., Rivera, A., and Zemp, M.: Recommendations for the compilation of glacier inventory data from digital sources, Annals of Glaciology, 50(53), 119-126, 2009.

Pellikka, P. and Rees, W. G.: Remote sensing of glaciers - Techniques for topographic, spatial and thematic mapping of glaciers, London, UK, 340 pp., 2009.

Rott, H. and Markl, G.: Improved snow and glacier monitoring by the Landsat Thematic Mapper, Proceedings of a workshop on Landsat Thematic Mapper applications, ESA, SP-1102, 3-12, 1999.

Schiefer, E. and Gilbert, R.: Reconstructing morphometric change in a proglacial landscape using historical aerial photography and automated DEM generation, Geomorphology, 88, 167-178, 2007.

Spotimages:

http://www.spotimage.com/automne_modules_files/standard/ public/p811_9d709b1bd850b040110d9d66db425dd2SPOT_ DEM_EN_140509.pdf, last access: 20 October 2009.
Trenberth, K. E., Jones, P.D., Adler, R., et al.: Observations: Surface and Atmospheric Climate Change. In: Climate Change 2007: The Physical Science Basis, Contribution of Working Group I to the Fourth Assessment Report of the Intergovernmental Panel on Climate Change, Cambridge University Press, Cambridge, United Kingdom and New York, NY, USA, 2007.

Tirismaps: https://portal.tirol.gv.at, last access: 29 May 2009.

UNESCO: Perennial ice and snow masses: a guide for compilation and assemblage of data for a world inventory, Technical Paper Hydrology 1. UNESCO/IASH, 1970.

Wittmann, H., von Blanckenburg, F., Kruesmann, T., Norton, K. P., and Kubik, P. W.: Relation between rock uplift and denudation from cosmogenic nuclides in river sediment in the Central Alps of Switzerland, J. Geophys. Res., 112, F04010, doi:10.1029/2006JF000729, 2007.

Würländer, R. and Eder, K.: Leistungsfähigkeit aktueller photogrammetrischer Auswertemethoden zum Aufbau eines digitalen Gletscherkatasters, Zeitschrift für Gletscherkunde und Glazialgeologie, 35, 167-185, 1998.

Würländer, R., Eder, K., and Geist, T.: High quality DEMs for glacier monitoring - image matching versus laser scanning, International Archives of Photogrammetry, Remote Sensing and Spatial Information Science, XXXV, Part B7, 2004. 